\title{
Role of Protein Vibration in Convergent and Divergent Thinking with Respect to Student's Performances
}

\author{
Brajagopal Majumder ${ }^{1,2}$, Aparajita Majumder ${ }^{1,2}$ \\ ${ }^{1}$ Retired Reader in Physics, Government Degree College, Agartala, India \\ ${ }^{2}$ Teacher, Sankaracharjya Vidya Yatan, Agartala, India \\ Email:bgmajumder@gmail.com
}

How to cite this paper: Majumder, B. and Majumder, A. (2017) Role of Protein Vibration in Convergent and Divergent Thinking with Respect to Student's Performances. Open Access Library Journal, 4: e3645. https://doi.org/10.4236/oalib.1103645

Received: May 3, 2017

Accepted: June 26, 2017

Published: June 29, 2017

Copyright $\odot 2017$ by authors and Open Access Library Inc.

This work is licensed under the Creative Commons Attribution International License (CC BY 4.0).

http://creativecommons.org/licenses/by/4.0/

\begin{abstract}
The paper focuses on the performances of the Students in Scholastic achievement as well as in creative activities. The performances of the students in creative activities have been analyzed statistically. These result in categorizing the Students in Convergent group and Divergent group. This classification is also supported by the role played by some memory related proteins. The role of protein has been considered here in the context of protein vibration approach. Our results of protein vibration approach are found to be compatible with those investigated by R Olga with EEG rhythms. The paper also suggests on the quality improvement of the students of Indian Schools by involving them in creative activities along with normal class content.
\end{abstract}

\section{Subject Areas}

Education, Psychology

\section{Keywords}

Convergent Thinking, Divergent Thinking, Creative Activity,

Protein Vibration, EEG Rhythms, Null Hypothesis

\section{Introduction}

Aristotle held the view that thinking process distinguishes men from other lower animals. According to Lock, "Thought is the perception of the agreement and disagreement of ideas". The scholars classified the world of experience in two forms: the material world and the world of thinking. Burton held the view that thinking results when there is persistent effort to examine the evidence which 
supports any belief, solution or conclusion which is suggested for acceptance of evidence" [1]. It is held that thinking and perception are complementary to each other; though perception requires stimuli while thinking involves abstract idea resulting in complete knowledge of a class of matter. Thinking generally starts to grow at the age of twelve of the individual. Regarding the characteristics of thinking, Koffka held "it is the characteristics of our thinking that we are able to carry out thought process abstractly with any sort of material, quite independently of the natural relation of things" [2].

From the definitions of thinking it is found that thinking includes 1) analysis 2) synthesis 3) purposive and 4) generalization. It is an established fact that thinking occurs abstractly through certain media. These are called vehicle of thought like images, concepts, symbols and reasoning. Considering all these parameters thinking in broad sense is classified as a) Convergent thinking and b) Divergent thinking.

The paper focuses not only on the conventional approaches of Convergent and Divergent thinking but it reflects on the role of protein responsible for memory and hyperactivity of the students. It also focuses on the experimental findings of classifying 90 students of standard VI to VIII in a semi-urban school with statistical analysis of the performances of the students. Thus the paper has two parts: biophysical approach and statistical approach. Since the paper has been developed not in conventional approach, it may not be comfortable to compare our findings with previous results. However, our findings with EEG rhythms have been found to be compatible with those of R. Olga. The innovative approach of the paper lies in considering the problem of Convergent and Divergent thinking in the context of protein vibration, which has recently been considered by the scholars as an alternative approach of addressing a number of problems of the students like mental disability, hyperactivity etc.

\section{Convergent and Divergent Thinking}

The term convergent thinking is associated with the ability of an individual to give the correct answer to standard questions. Thus it is oriented toward deriving the single best and well established answer to a problem [3]. As a result there is no room for ambiguity. Thus recalling the correct answer or working out through decision making strategies constitutes the beast characteristic of convergent thinking. Hence, convergent thinking emphasizes on speed and accuracy. It also focuses on recognizing the familiarity and reapplying technique as well as rapid recalling stored information. The solution thus derived at the end of convergent thinking is the best possible answer in majority of the time. For example-if there is question like what is the capital of India, the simple answer is Delhi. If an individual knew the answer, he can straight forwardly answer. There will not remain any ambiguity in replying this question. This is the outcome of convergent thinking.

In construct, divergent thinking is the type of thinking that associates with an abstract or new problem which has many possible answers or solutions or out- 
comes. So, to give the correct answer, you are to be more creative. Thus divergent thinking involves creativity or vice-versa. For example, a poet or a story writer, he should have the capability of divergent thinking since he is to write the poem or story from endless supply of words or characters. Thus creativity is directly related to divergent thinking.

Now the question is what does creativity mean?

"Creativity is the ability of an individual to come up with new original and unique solutions to a problems or ideas". Creativity is found in paintings, in design of buildings, in poems, in novels etc. Let as focus our attention to the example cited by instructor W. Goodfriend. [4]

Students of high school may be given an assignment of creating a structure which will be able to hold an egg that can be dropped without breaking the egg from 15 feet height. The students were asked to create the structure from the following three possibilities.

1) "A wooden box fitted with straw.

2) A cotton pillow with the egg sewed inside.

3) A plastic container filled with water".

The students have to be creative with these three ideas since all might work better or worse. Thus to be creative the students have to possess the abilities of divergent thinking. On the other hand, creativity is directly associated with intelligence. According to Robert Sternberg-a famous Psychologist [5], intelligence are of three types namely 1) synthetic intelligence 2) analytic intelligence and 3) practical intelligence. The ability to see or analyze a problem in a new and unique dimension constitutes as synthetic intelligence while the ability to analyze the relationships or association among ideas and hence forth application of these criteria to the problems constitutes as analytic intelligence. Finally ability to come up with new ideas or ways of solving a problem constitutes as practical intelligence.

On the other hand, mood has got direct relationship with creativity resulting in divergent thinking. Different experiments conducted by different scholars and carrying out a task with creative thinking have effects on one's mood. It is an established fact that mood (emotion) can affect cognition process while cognition process, in the context of recent approaches, can also affect one's mood. This provides considerable support for the fact that mood and cognition are inversely related to each other. From this, it is held that divergent and convergent thinking impact mood (emotion) in opposite ways, while divergent thinking leads to positive mood, convergent thinking leads to negative mood. These are some of the characteristics of convergent and divergent thinking.

A clear measurement shows while divergent thinking is associated with creativity, convergent thinking may directly or indirectly results in memory traces. Thin means stable memory may turn as outcome of convergent thinking. A good number of examples may be cited in this respect [5]. It reveals from a series of standard intelligent tests with respect to the measure of both the convergent and divergent abilities of adolescents. Distinction between divergent and convergent thinking emerges also in case of results which indicate who scored high 
on divergent thinking are found significantly high in word fluency and reading scores. Moreover, those who score high in divergent thinking found mature in this perceptual process and found also adequately controlled.

Conversely, subjects with high convergent thinking are found to score higher grade in their examinations and answers the questions point wise without any hesitation. However, all these investigations found upon the development of cognitive and perpetual aspects of personality among both the divergent and convergent thinkers. But these do not belong to their attitude structure.

\section{Methodology}

\subsection{Biophysical Approach}

Experiments with Electroencephalograph (EEG) were conducted to observe changes in brain activity of the individual during both convergent and divergent thinking. Different pattern of changes were found during each type of thinking with the application of different EEG rhythm. The findings of the demonstrations conducted by R. Olga [6] reveal as

“1) Both convergent and divergent thinking produced significant desynchronization of ALPHA 1, 2 rhythms in a control group of subject who was taking rest.

2) Convergent thinking induced coherence increase in Theta 1 band which was more caudal and right sided.

3) Divergent thinking demonstrated amplitude decrease in the caudal regions of the cortex in the form of Theta 1 and 2 bands.

4) The large increase in amplitudes and coherence indicates close iterations between both hemispheres in the brain.

5) The right hemisphere and the cognitive axis, coupling of left occipital-right frontal in contrast to the right occipital-Left frontal axis which characterize analytical thinking, may reflect the EEG pattern of unconscious metal processes during divergent thinking."

Though the findings are found significant for measuring convergent and divergent thinking, yet the reasons of these findings in the brain had not explained by the scholar. In a paper the authors [7] suggested in the light of "protein vibration" that proteins and protein receptors are responsible for learning and memory formation. Basing on their suggested approach of "protein vibration", it has been shown by the authors that proteins of large molecular weights are responsible for stable memory while proteins of middle range and small molecular wrights are responsible respectively for middle term and short term memory. The paper focused on the underlying mechanism of protein activation with respect to learning and memory traces in the brain with the application of four basic types of EEG rhythms [7] of amplitudes 20 - 100 and 150 - 350 microvolt and frequencies in the range of 0.5 to 30 cycles per second. Four types of rhythms [8] are illustrated in Figure 1.

It is an established fact that CAMP stimulates protein kinase (PK-A) that phosphorylates the $\mathrm{K}+$ channels on the membrane resulting in short term memory 
(1)

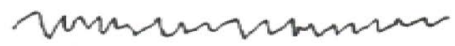

(2)

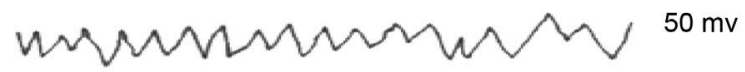

(3)

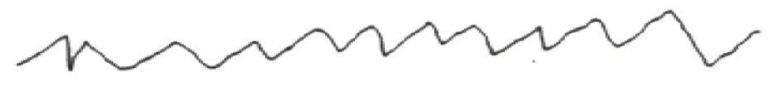

(4)

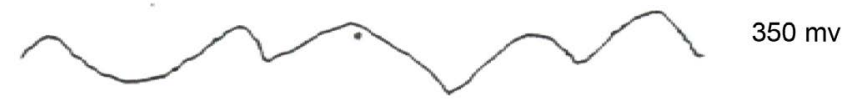

Figure 1. Schematic representation on four types of EEG rhythms. (Curtsy Bobsky, E. B, and others: Human Physiology, MIR publication).

(STM) or CAMP response to element binding with respective proteins in long term memory. It is also an established fact [9] that when an electrical signal gets to a neuron, the structure of membrane lipid is changed and passes into a new state with intensifying RNA activity and its constituent protein synthesis. If there be not any change, nothing will be recorded. But if the cell passes into a new state with some new property, an imprint of the received information is left and a trace of memory is emerged. At this stage the structure becomes different and the oriented proteins enter the lipids and stabilize new structure. Permanent alterations in the structure and number of synapse are found in long term memory. These mean there occur changes in the electrical activity of specific regions of the brain due to different learning experiences [7]. The ID names of some memory related proteins are as Table 1.

Table 1. The id name of some memory related proteins with molecular masses.

\begin{tabular}{cc}
\hline ID Name of the Protein & Molecular mass in S. I. Units \\
CD 40 L /CD154 & $\mathrm{m}=16.9$ Kilodalton \\
BCPM 1 & $\mathrm{~m}=19.98$ Kilodalton \\
CSP 24 & $\mathrm{~m}=24$ Kilodalton (Phospo protein) \\
32 P04 & $\mathrm{m}=32$ Kilodalton (Phospo protein) \\
Mspi 42 & $\mathrm{~m}=42$ Kilodalton (merozoite surface protein) \\
Cam-k & $\mathrm{m}=54$ Kilodalton \\
TAFI/DYT 3 & $\mathrm{~m}=250$ Kilodalton
\end{tabular}

Now let us examine the vibration characteristics of proteins responsible for learning and thereby memory traces with the application of EEG rhythms of amplitudes 20 - 100 and 150 - 300 microvolt as initial stimulating energy. The natures of vibration with respect to proteins of different molecular weights are diagrammatically shown as Figure 2.

The vibration frequency and vibration energy of the concerned protein can be evaluated by using one dimensional Schroclinger's Equation. The reason of considering one dimensional Schrodinger's Equation [7] lies in the fact that an electrostatic force can control atomic motion in a protein. For a protein [10] this can 


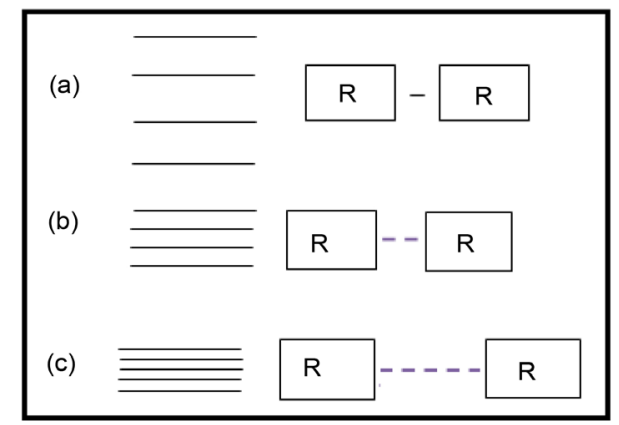

Figure 2. Vibration energy spacing of protein molecules.

be divided into two components-a large and a small.

Conformational substrates for the protein in its native state may correspond to the same position " $r$ " of the particle at time " $t$ ". Thus $r(t)$ can be split into two independent components.

$$
r(t)=r_{v}(t)+r_{t}(t)
$$

where $r_{v}(t)$ stands for the vibration component about the equilibrium position with the host molecule and $r_{t}(t)$ stands for transient component about the equilibrium position at time $t$. The electrostatic force required for this purpose may be deduced from the relation

$$
f=-\mathrm{d} v / \mathrm{d} r
$$

Which means force is nothing but rate of change of potential

$$
V(r)=V\left(r_{v 9} r_{t}\right) 1 / 2\left[k_{v}\left(r_{1}\right) r_{v}^{2}\right]+U\left(r_{1}\right)
$$

where $k_{v} r_{1}$ is the vibration component of the force and $U(r)$ stands for the translational component of the same. Since the translational component of the force is very small with respect to the vibration component of the same the second term of Equation (1) may be neglected. So Equation (1) may be rewritten as

$$
V(r)=V\left(r_{v}\right)=1 / 2\left[k_{v}\left(r_{v}\right) r_{v}^{2}\right]
$$

The magnitude of this transformed energy may be evaluated by following quantum mechanical treatment of harmonic oscillator. By inserting vibration potential energy function, we may write $f=-\mathrm{d} v / \mathrm{d} r$, which stands for the rate of change of potential energy with change of co-ordinate. Let us now state with $f=$ $-k r$ which on integration leads to potential energy $v=1 / 2 k r^{2}$. This potential energy rises parabolic on either side of the equilibrium as illustrated [11] in Figure 3.

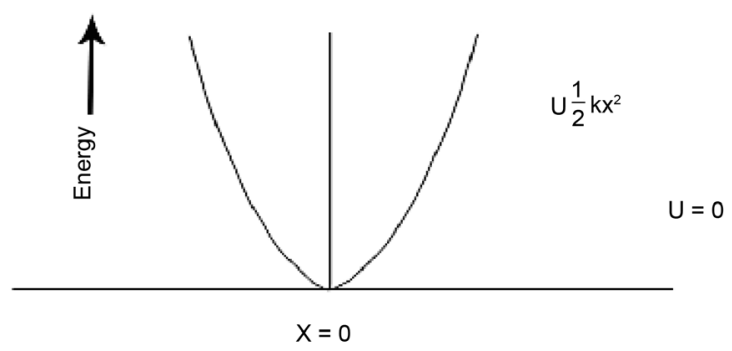

Figure 3. Oscillation of vibrating particle. 
Inserting potential energy as

$$
V=\frac{1}{2} k r^{2}
$$

The one dimensional Schrodinger's Equation

$$
\frac{-h^{2}}{8 \pi^{2} m} \cdot \frac{\mathrm{d}^{2} \psi}{\mathrm{d} r^{2}}+v(r) \psi=\varepsilon \psi
$$

which turns to

$$
\frac{-h^{2}}{8 \pi^{2} m} \cdot \frac{\mathrm{d}^{2} \psi}{\mathrm{d} r^{2}}+\frac{1}{2} k r^{2} \psi=\varepsilon \psi
$$

The energies of the allowed vibration states derived from the solutions of the Schrodinger's Equation are

$$
\vartheta_{\text {vib }}=\left(v+\frac{1}{2}\right) \frac{h}{2 \pi} \sqrt{\frac{k}{m}}, v=0,1,2
$$

While the expression for vibration frequency stands as

$$
\vartheta_{\text {vib }}=\frac{1}{2 \pi} \sqrt{\frac{k}{m}}
$$

The vibrations occurring in protein depends on molecular weight of the concerning proteins available in particular portions of the brain. Thus, frequent vibrations, as the authors held, are created in light proteins of small molecular weight while slow vibrations are created in proteins of middle range molecular weight.

The expression for vibration energy is

$$
E_{\mathrm{vib}}=\frac{h}{2 \pi} \sqrt{\frac{k}{m}}
$$

Basing on the approaches the author evaluated the vibration frequencies and energies of a number of proteins with different molecular weights responsible for learning and memory traces [7] [12] and for a number of degenerative and TSE diseases [13] from the view point of this hypothetical approach of protein vibration.

Vibration frequencies and $\left(\mathrm{m}^{-1}\right)$ and Vibration energies of some related proteins as mentioned in Table 1 are tabled in Table 2 and Table 3.

Table 2. Vibrational frequencies $\left(\mathrm{m}^{-1}\right)$ of some memory related Proteins with molecular weights.

\begin{tabular}{cccccccc}
\hline $\begin{array}{c}\text { External } \\
\text { electrical stimuli in } \\
\text { microvolt }\end{array}$ & $\mathrm{m}=16.9$ & $\mathrm{~m}=19.98$ & $\mathrm{~m}=24$ & $\mathrm{~m}=32$ & $\mathrm{~m}=42$ & $\mathrm{~m}=54$ & $\mathrm{~m}=250$ \\
\hline 20 & 0.71 & 0.67 & 0.60 & 0.52 & 0.46 & 0.40 & 0.18 \\
25 & 0.81 & 0.74 & 0.68 & 0.58 & 0.51 & 0.45 & 0.25 \\
50 & 1.14 & 1.05 & 0.96 & 0.83 & 0.72 & 0.63 & 0.29 \\
100 & 1.60 & 1.49 & 1.34 & 1.16 & 1.01 & 0.90 & 0.41 \\
150 & 1.93 & 1.83 & 1.63 & 1.42 & 1.24 & 1.06 & 0.50 \\
250 & 2.23 & 2.37 & 2.15 & 1.86 & 1.62 & 1.43 & 0.66 \\
350 & 3.03 & 2.67 & 2.55 & 2.20 & 1.92 & 1.69 & 0.79 \\
\hline
\end{tabular}


Table 3. Vibrational Energy of Proteins at Initial and Final Levels.

\begin{tabular}{|c|c|c|c|c|c|c|c|}
\hline \multirow[b]{2}{*}{ Initial energy } & \multicolumn{7}{|c|}{ Final energy $\times 10^{22} \mathrm{~J}$} \\
\hline & $\mathrm{m}=16$. & $\mathrm{m}=19.98$ & $\mathrm{~m}=24$ & $\mathrm{~m}=32$ & $\mathrm{~m}=42$ & $\mathrm{~m}=54$ & $\mathrm{~m}=250$ \\
\hline $\begin{array}{l}\text { 1) Initial energy due to } 20 \\
\text { microvolts equaling to } \\
11.0 \times 10^{-22} \text { joules }\end{array}$ & 14.29 & 12.89 & 11.91 & 10.32 & 9.13 & 7.94 & 3.57 \\
\hline $\begin{array}{l}\text { 2) Initial energy due to } 25 \\
\text { microvolts equaling to } \\
13.75 \times 10^{-22} \text { joules }\end{array}$ & 16.08 & 15.06 & 13.50 & 11.51 & 10.12 & 8.93 & 4.17 \\
\hline $\begin{array}{l}\text { 3) Initial energy due to } 50 \\
\text { microvolts equaling to } \\
27.50 \times 10^{-22} \text { joules }\end{array}$ & 22.64 & 20.54 & 19.06 & 16.48 & 14.29 & 12.51 & 5.75 \\
\hline $\begin{array}{l}\text { 4) Initial energy due to } 100 \\
\text { microvolts equaling to } \\
55.00 \times 10^{-22} \text { joule }\end{array}$ & 31.77 & 29.66 & 26.61 & 23.03 & 20.05 & 17.87 & 8.41 \\
\hline $\begin{array}{l}\text { 5) Initial energy due to } 150 \\
\text { microvolts equaling to } \\
82.50 \times 10^{-22} \text { joule }\end{array}$ & 38.32 & 35.42 & 32.37 & 28.20 & 24.62 & 21.05 & 9.93 \\
\hline $\begin{array}{l}\text { 6) Initial energy due to } 250 \\
\text { microvolts equaling to } \\
137.50 \times 10^{-22} \text { joule }\end{array}$ & 44.28 & 43.26 & 42.69 & 36.93 & 32.17 & 28.39 & 13.10 \\
\hline $\begin{array}{l}\text { 7) Initial energy due to } 350 \\
\text { microvolts equaling to } \\
192.50 \times 10^{-22} \text { joule }\end{array}$ & 60.17 & 54.18 & 50.64 & 43.69 & 38.13 & 33.56 & 15.68 \\
\hline
\end{tabular}

\subsection{Statistical Approach}

A study was conducted with the students of standard VI, VII and VIII of a Higher Secondary School in a Semi-urban area. The number of students in each class was 30 (Thirty). The students were administered one question paper in M.C.Q Pattern. The question consists of three Subjects-Language, Mathematics and Science. Each subject consists of 10 (Ten) questions carrying one mark for each question. The test was conducted with the following hypothesizes.

Hypothesis of the study.

1) Those who do well (securing $70 \%$ and above) in any subject in M.C.Q (Test of Reference) are expected to do well in School Test. They are found to be well in memory test. They may belong to convergent groups.

2) Those who fail to secure good marks ( $70 \%$ and above) in any subject in M.C.Q test may also fail to secure good marks ( $70 \%$ and above) in any of the subjects mentioned above in School Test. This means that these students may be weak in memorization.

3) The Students who are weak in memorization may do well in creative activity and may belong to divergent groups.

\section{Result and Discussions}

With these hypothesizes in mind answer script were evaluated by the teachers of the school. Class-wise scores both in test of reference and in School Test are 
analyzed [14] as Tables 4-6.

1) Class-VI

Table 4. Performance of the students of standard VI in school test and also in test of reference in Language, Science and Math.

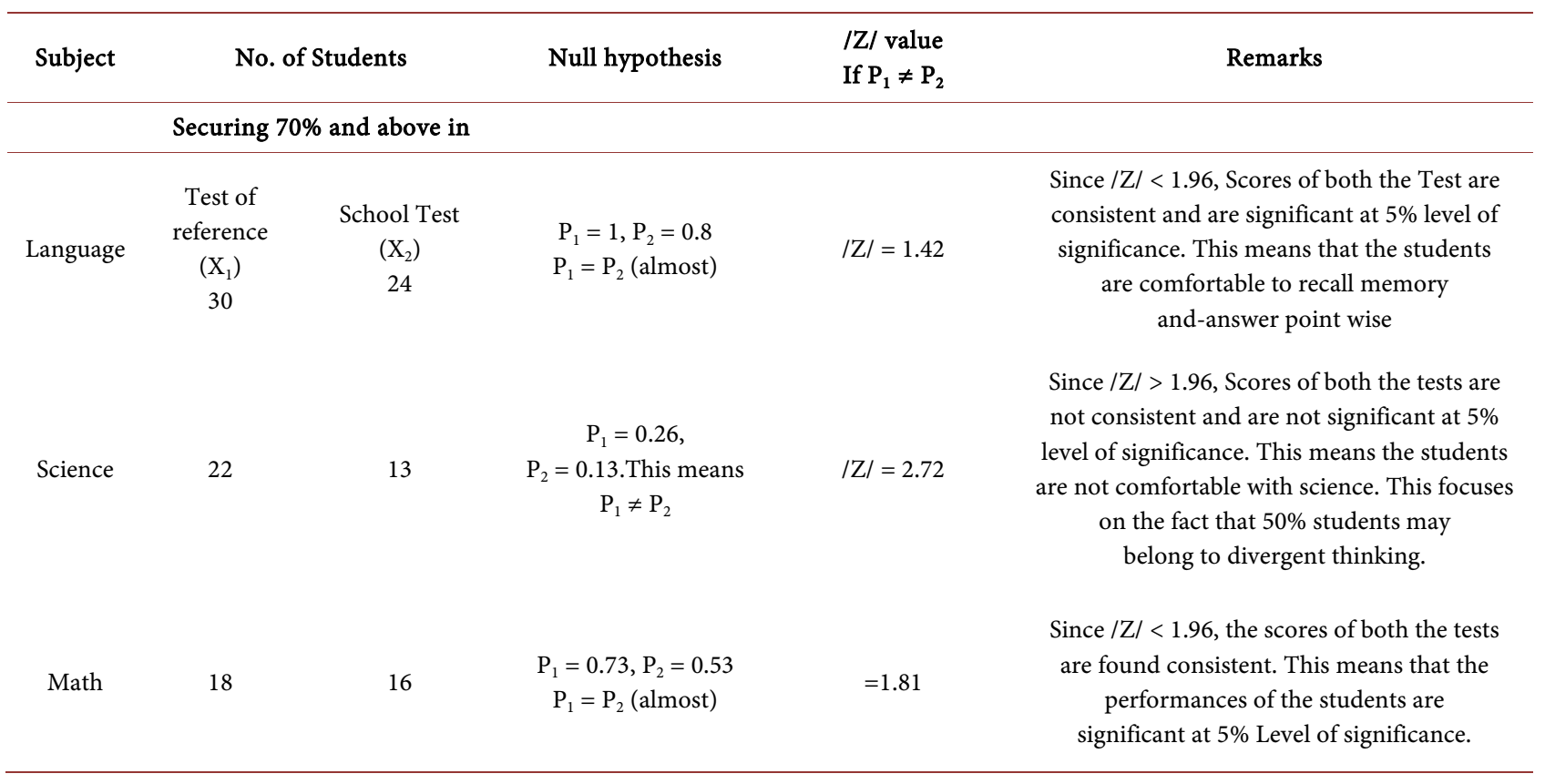

Source: Field study.

\section{2) Class-VII}

Table 5. Performance of the students of standard VII in school test and also in test of reference in Language, Science and Math.

\begin{tabular}{|c|c|c|c|c|c|}
\hline \multirow[t]{3}{*}{ Subject } & \multirow{2}{*}{\multicolumn{2}{|c|}{$\begin{array}{c}\text { No. of Students } \\
\text { Securing } 70 \% \text { and above }\end{array}$}} & \multirow{3}{*}{$\begin{array}{l}\text { Null hypothesis } \\
\qquad \mathrm{P}_{1}=\mathrm{P}_{2}\end{array}$} & \multirow{3}{*}{$\begin{array}{l}/ \mathrm{Z} / \text { value } \\
\text { if } \mathrm{P}_{1} \neq \mathrm{P}_{2}\end{array}$} & \multirow{3}{*}{ Remarks } \\
\hline & & & & & \\
\hline & Test of reference & School test & & & \\
\hline Language & $\begin{array}{c}\text { Test }\left(\mathrm{X}_{1}\right) \\
28\end{array}$ & $\begin{array}{l}\left(\mathrm{X}_{2}\right) \\
18\end{array}$ & $\begin{array}{c}\mathrm{P}_{1}=0.933 \\
\mathrm{P}_{2}=0.600 \\
\mathrm{P}_{1}=\mathrm{P}_{2} \text { (almost) }\end{array}$ & $\mid \mathrm{Z} /=3.20$ & $\begin{array}{l}\text { Since } / \mathrm{Z} />1.96 \text {, Scores }(70 \% \text { and above) obtained } \\
\text { by the students }\left(\mathrm{X}_{1}=28, \mathrm{X}_{2}=18\right) \text { on the basis of test } \\
\text { of reference and those of school test are not } \\
\text { consistent. This is because of the fact that the } \\
\text { students who can do well in M.C.Q are not } \\
\text { comfortable with memory based test of the school. }\end{array}$ \\
\hline Science & $\begin{array}{c}\left(\mathrm{X}_{1}\right) \\
5\end{array}$ & $\begin{array}{l}\left(\mathrm{X}_{2}\right) \\
17\end{array}$ & $\begin{array}{c}\mathrm{P}_{1}=0.23 \\
\mathrm{P}_{2}=0.77 \\
\mathrm{P} \neq \mathrm{P}_{2}\end{array}$ & $|Z|=2.25$ & $\begin{array}{l}\text { Since } / Z />1.96 \text {, the scores of the both the tests are } \\
\text { not consistent. So there is no significance in correct } \\
\text { answer given by the students in our test of reference, } \\
\text { while a good number of students (more than 50\%) } \\
\text { do well in school test in which students feel } \\
\text { comfortable since school test questions } \\
\text { mostly advocate for memorization. }\end{array}$ \\
\hline Math & 27 & 18 & $\begin{array}{c}\mathrm{P}_{1}=0.90 \\
\mathrm{P}_{2}=0.60 \\
\mathrm{P}_{1} \neq \mathrm{P}_{2}\end{array}$ & $\mid \mathrm{Z} /=2.8$ & $\begin{array}{l}\text { Since /Z/ > 1.96, Scores of two tests are not } \\
\text { consistent. Thus these are not significant at } 5 \% \text { level } \\
\text { of significance. In school examination the students } \\
\text { find little scope to do well, while in M.C.Q pattern of } \\
\text { question they feel much comfortable. }\end{array}$ \\
\hline
\end{tabular}

Source: Field study. 


\section{3) Class-VIII}

Table 6. Performance of the students of standard VIII in school test and also in test of reference in Language, Science and Math.

\begin{tabular}{|c|c|c|c|c|c|}
\hline \multirow[t]{2}{*}{ Subject } & \multicolumn{2}{|c|}{ No. of Students Securing $70 \%$ and above } & \multirow{2}{*}{$\begin{array}{c}\text { Null hypothesis } \\
P_{1}=P_{2}\end{array}$} & \multirow{2}{*}{$\begin{array}{l}/ \mathrm{Z} / \text { value } \\
\text { If } \mathrm{P}_{1} \neq \mathrm{P}_{2}\end{array}$} & \multirow{2}{*}{ Remarks } \\
\hline & Test of reference & School test & & & \\
\hline Language & $\begin{array}{c}\left(\mathrm{X}_{1}\right) \\
28\end{array}$ & $\begin{array}{c}\left(\mathrm{X}_{2}\right) \\
23\end{array}$ & $\begin{array}{c}\mathrm{P}_{1}=0.933 \\
\mathrm{P}_{2}=0.766 \\
\mathrm{P}_{1}=\mathrm{P}_{2} \text { (almost) }\end{array}$ & $/ Z /=1.91$ & $\begin{array}{l}\text { Since } / \mathrm{Z} /<1.96 \text {, the data are consistent } \\
\text { with null hypothesis at } 5 \% \text { Level of } \\
\text { significance. This means scores of the } \\
\text { students under } \mathrm{X}_{1} \text { and } \mathrm{X}_{2} \text { are almost in } \\
\text { parity to each other. }\end{array}$ \\
\hline Science & 13 & 8 & $\begin{array}{c}\mathrm{P}_{1}=0.26 \\
\mathrm{P}_{2}=0.42 \\
\text { Null hypothesis is } \\
\text { valid }\end{array}$ & $\mid \mathrm{Z} /=1.36$ & $\begin{array}{l}\text { Since } / Z /<1.96 \text {, the data are consistent } \\
\text { with null hypothesis at } 5 \% \text { level of } \\
\text { significance. This means } 8 \text { students out } \\
\text { of } 13 \text { (Thirteen) students who did well } \\
\text { in school test, did well in test of } \\
\text { reference, while the rest number of } \\
\text { students failed to score } 70 \% \text { and above. }\end{array}$ \\
\hline Math & 15 & 5 & $\mathrm{P}_{1} \neq \mathrm{P}_{2}$ & $\mid Z /=2.95$ & $\begin{array}{l}\text { Since } / \mathrm{Z} />1.96 \text {, the data are not } \\
\text { consistent. This means that the } \\
\text { number of students scoring } 70 \% \text { and } \\
\text { above in Mathematics in our test are } \\
\text { not in parity with those in } \\
\text { Math of their school test. }\end{array}$ \\
\hline
\end{tabular}

Source: Field study.

\section{Overall Remarks of the Tests}

1) The students of VI, standard are found to do well both in school test and also in our test of reference in Language and Math where scores are significant at $5 \%$ Level of significance. This means the scores of the students in both the subjects are in parity with each other. But the performance of the students in Science is widely different.

2) The performances of the students of VII standard in all the three subjects are not found in parity with respect to both the tests namely test of reference and the school test. No scores are found to be significant. As for example, the students who do well in our test in Math and Language, failed to do well in school test. On the other hand, reverse scores is found in case of science.

3) Performances of the students of VIII standard are found well in test of reference and also in school test with respect to Language and Science. The scores are found significant at $5 \%$ Level significance. This means some of the students are almost in equal level of understanding. On the other hand, performance of the students in Math in both the tests namely test of reference and also in school test are not found in parity with each other.

From the above discussion, it is held that performance of the students of VI, VII and VIII standard may be classified as

a) Some students of VI standard do well in Language and Math but not in Science.

b) Few no of students of VII standard do well in Language only while the 
scores of the students in Science and Math are not worthy to be mentioned.

c) Some students of VIII standard are found to do well in Language and Science in both the tests while only handful students scores $70 \%$ and above in Math.

From these, heterogeneous observations are found to occur. It reveals that students of VI \& VII standard are weak in Science while the students of VIII standard are found weak in Math. Both Math \& Science constitute as subjects of reasoning. However, it can be held that hypothesis (1) and (2) are partially justified. For proper classification of the students in convergent and divergent group as well as justification of hypothesis (3), we have conducted creatively tests for all the students of VI, VII and VIII standard. The results of creativity test may be analyzed as.

The students of the VI standard who were found weak in science in school test asked for drawing as they like. In total 23 students took part in drawing of their own choice. Each of these students was provided one drawing sheet. 23 students of VII standard who were found weak in science in school test were provided one Match Box each and were asked to design anything of their choice with the sticks of the Match Box. 21 students of VIII standard who were found weak in Match in school test were provided loose paper and scissor each and were asked to design and prepare decorative articles they can with these papers.

The findings are tabled as Table 7.

Performance of the students of the standard VI, VII and VIII in creative activity.

4) Class-VI, VII, VIII

Table 7. Performance of the students of the standard VI, VII and VIII in creative activity.

\begin{tabular}{|c|c|c|c|c|c|}
\hline $\begin{array}{c}\text { Class and } \\
\text { subject of } \\
\text { creative works }\end{array}$ & $\begin{array}{c}\text { No. of students } \\
\text { who do well in } \\
\text { creative test }\end{array}$ & $\begin{array}{l}\text { No. of students } \\
\text { who failed to } \\
\text { scores } 70 \% \\
\text { and above }\end{array}$ & $\begin{array}{l}\text { Null hypothesis } \\
\qquad P_{1}=P_{2}\end{array}$ & If $P_{1} \neq P_{2}$ & Remarks \\
\hline $\begin{array}{l}\text { Class VI } \\
\text { Drawings }\end{array}$ & $X_{1}=11$ & $\begin{array}{c}\text { In school test } \\
\begin{array}{c}\text { (Science) } \\
\mathrm{X}_{2}=19\end{array}\end{array}$ & $\begin{array}{c}\mathrm{P}_{1}=0.47 \\
\mathrm{P}_{2}=0.63 \\
\mathrm{P}_{1}=\mathrm{P}_{2}\end{array}$ & $|\mathrm{Z}|=1.45$ & $\begin{array}{l}\qquad / \mathrm{Z} /<1.96, \text { the scores are very } \\
\text { significant at } 5 \% \text { Level of significance. } \\
\text { This means the students who failed to } \\
\text { do well in science in school test could } \\
\text { do well in spontaneous } \\
\text { activity of creativity. }\end{array}$ \\
\hline $\begin{array}{c}\text { Class VII and } \\
\text { use Match sticks }\end{array}$ & $X_{1}=16$ & $\mathrm{X}_{2}=19$ & $\begin{array}{c}\mathrm{P}_{1}=0.69 \\
\mathrm{P}_{2}=0.43 \\
\mathrm{P}_{1} \neq \mathrm{P}_{2}\end{array}$ & $\mid \mathrm{Z} /=1.85$ & $\begin{array}{l}|\mathrm{Z}|<1.96, \text { the scores are scores are } \\
\text { very significant at } 5 \% \text { level of } \\
\text { significance. This means students } \\
\text { who fail to do well in science in school } \\
\text { test could do well creativity. }\end{array}$ \\
\hline $\begin{array}{l}\text { Class VIII and } \\
\text { use of papers } \\
\text { for making } \\
\text { drawing } \\
\text { materials }\end{array}$ & $\mathrm{X}_{1}=12$ & $\mathrm{X}_{2}=15$ & $\begin{array}{c}\mathrm{P}_{1}=0.57 \\
\mathrm{P}_{2}=0.71 \\
\mathrm{P}_{1} \neq \mathrm{P}_{2}\end{array}$ & $/ Z /=1.75$ & $\begin{array}{l}|Z|<1.96, \text { the scores are significance at } \\
5 \% \text { level of significance. This means } \\
\text { that } 12 \text { students could do well in } \\
\text { creativity who failed to score } 70 \% \\
\text { and above in school test in science. }\end{array}$ \\
\hline
\end{tabular}


It reveals from the table that 11 (Eleven) students of Class VI standard, 16 (Sixteen) students of Class VII standard and 12 students of VIII standard who failed to score $70 \%$ and above in school tests in science and Mathematics could do well in creative activities. These students may belong to divergent group. On the other hand, 7 students of VI standard, 7 students of VII standard and 9 students of VIII standard who were found to do well in school test in science and Mathematics failed to do well in creative activities. This means these students feel comfortable in memorization. They may belong to convergent group. However, four students of VI standard were found to do well both in school test in science and also in creative actives. They being the students of convergent group are found exceptional.

From the above finding it can be held that basing on creative tests the students could be classified in divergent group and convergent group. From the creative tests it is found that the students who failed to score $70 \%$ and above in school Test in science and Mathematics, could do well in creative tests while students who scored $70 \%$ and above in school tests in science and Mathematics failed to do well in creative test with an exception of few students [4] who do well in both creative and school tests. Thus the hypothesis 3 is justified and the students can be classified in both divergent and convergent groups.

It reveals from Table 2 that more the molecular weight of protein molecule is, the less would be the frequency of vibration. On the other hand, more the frequency of vibration is, less would be molecular weight of the protein. This means there is frequent vibrations in case of protein of less molecular weight while reverse may be found in case of protein of higher molecular mass.

From Table 2 it is found that the magnitudes of vibrations are lower in case of protein of less molecular weight $\mathrm{m}=16.9 \mathrm{KD}$ where $\alpha, \beta$, and $\theta$ rhythms are generated due to input energies of electrical oscillation of low amplitudes 20, 25, 50 and 100 microvolt's. Since these vibrations are found to occur frequently and input output differential is well, these may takes part in learning of unorganized events. As a result retentively will be less. This may be compatible with the findings of R. Olga [6] where it was held that divergent thinking is demonstrated with amplitude decrease in the caudal regions of the cortex in the form of $\theta-1$ and 2 bands.

On the other hand, magnitudes of vibration generated in proteins of molecular weights $\mathrm{m} \geq 54 \mathrm{KD}$ due to $\alpha, \beta$, and $\theta$ rhythms having amplitudes (150 - 350) microvolt with significant difference between input output energies, may take part in learning of organized events. So, the possibility of high retentively holds good. This is also found compatible with the findings of R. Olga [6] where it was held that convergent thinking induced coherence increase in $\theta-1$ band which was more caudal. Proteins of molecular weight between (16 - 24) KD respond well to higher electrical amplitudes (250 - 350) microvolt and input output differential are high which correspond to Theta region. These are found to occur with learning events during deep sleep. This is found to be compatible with the findings of R. Olga [6] where it was held that large increase in amplitudes and coherence indicates close innervations between by both hemispheres in brain 
resulting both convergent and divergent thinking in the subjects taking rest.

Thus our theoretical approach of protein vibration is found to be in parity with our findings of field study on memory tests as well as creativity tests conducted with a sample size of 90 populations in a semi-urban Higher Secondary Institution.

\section{Conclusions}

In spite of having clear distinction between convergent and divergent thinking, an attempt has been taken to focus the matter as a case of one's performance both as convergent and divergent thinker. From the statistical approach, it reveals that the best performing students both in our test of reference or in school test have been found to be comfortable in memorization. On the other hand, students not doing well in test of reference and also in school test are found to be weak in memorization. They have been identified as divergent thinkers and they are found to do well in creative activities which as the scholar held, constitute the bases of divergent thinking.

However, convergent thinking is not beyond criticism. It has been mentioned by the scholars that convergent thinking is said to devalue minority argument. It has also been shown by De Dreu and others [15] that "a pattern emerges under convergent thinking condition when presented with either majority support for persuasive arguments, produced more positive attitudes on focal issues".

In this context, our proposed "Protein Vibration" approach may serve as a best tool of distinguishing convergent thinking and divergent thinking where it is mentioned that proteins or protein receptors of large molecular weights are responsible for stable memory which advocates for convergent thinking, while proteins of small molecular weights vibrate frequently resulting in short memory. This indicates that the individual may not be comfortable with memorization resulting incapability of point wise answers. These findings may be associated with divergent thinking. Thus these findings constitute the innovative approach of the paper which is different from conventional studies on the problem.

However, the statistical approach undertaken by the author may not be taken as standard one since it has neither been compared with similar study nor been standardized statistically. In spite of these observations it can be resolved that our findings with "Protein Vibration" have found to be compatible with those observed by R. Olga [6]. Hence, the school authority can arrange for creative activities so that students of divergent thinking may make their future career accordingly. Here lies the significance of the present paper based on which the school authority may entrust the responsibility of counseling the students for better performance in scholastic achievement as well as in creative activities. This may open the door for the school authority and the department of school education to arrange for qualitative performance of the students.

\section{Acknowledgements}

The author is thankful to Mr. D.C Pal, Headmaster of Bardwali Higher Second- 
ary School, Agartala, Tripura, India for his Co-operation in Conducting Test of Reference and Creativity Test for Students of standard VI, VII, VIII along with his associates namely Mr. S. Pal, Mr. N. Rakhit, Mrs. S. Sengupta, Mr. P. Bhowmik, Mr. K. Debbarma, Mr. K. Sen, Mr. B. Ghosh, Mr. P. Saha, Mr. K. Tripura, Mr. S. Sutradhar, and Mr. N. Dey. The author does not miss to express his gratitude to Mrs. S.R. Dey, Ex-Headmistress of the School for according permission to conduct the tests with the Students. The author is also thankful to Miss. Joysree Sutradhar for undertaking the Computer Works of the Paper.

\section{References}

[1] Burton, W.H. Education for Effective Thinking and Others

[2] Kaffaka. Growth of Mind.

[3] Sara, L. (2012) Critical Thinking in Problem Solving; A Perspective for the Language Arts Teacher. Retrieved 1 April.

[4] Good Friend, W. Lesson Transcript. Collected from Net.

[5] (2009) Strategies of Divergent Thinking. University of Washington. Retrieved June.

[6] Razoumnikov, O.M. (2000) Function Organization of Different Brain Aries during Convergent and Divergent Thinking: An EEG Investigation. Cognitive Brain Research, 10, 11-18. https://doi.org/10.1016/S0926-6410(00)00017-3

[7] Majumder, B.G. and De, U.C. (2013) Role of Protein Vibration in Learning and Memory-A Mathematical Approach. International Journal of Biophysics, 3, 33-37.

[8] Bobsky, E.B. and Khodorov, B.I. (1975) Human Physiology. MIR Publication and Co. and Others, Moscow, 2, 274.

[9] Kovalyoba, A. (1990) Mapping Memory's Track. Science USSR, 4, 95-96.

[10] Gotze, W. and Sjogren, L. (1992) Relaxation Processes in Super Cooled Liquids. Reports on Progress in Physics, 55, 241-376.

[11] Barrow, E.B., Khodorov, B.I., Kosisky, G.I., et al. (1975) Human Physiology. Vol., 2, MIR Publication and Co., Moscow, 274.

[12] Majumder, B.G. (2014) Smelling: A Pathway to Instant Memory. International of Biophysics, 4, 16-22.

Majumder, B.G. (2015) Role of Protein Vibration in Emotion, Attention, Learning and Memory. International of Biophysics, 5, 1-11.

[13] Majumder, B.G. and De U.C. (2016) Vibration Characteristics of Misfolded Proteins and Their Consequences. International Journal of Biochemistry and Biophysics, 4, 4-9.

Majumder, B.G. (2016) An Analytical Approach to Anti-Parkinsonian Effect of Bacopa Monnari in the Context of Protein Vibration. International Journal of Biochemistry and Biophysics, 6, 21-25.

[14] Gupta, S.C. and Kapoor, V.K. (1997) Fundamentals of Mathematical Statistics. Sultan Chand and Sons, New Delhi, 11.23-12.23.

[15] De Dreu, C.K.W., De Vries, N.K., Gordijn, E.H. and Schuurman, M.S. (1999) Convergent and Divergent Processing of Majority and Minority Arguments: Effects on Focal and Related Attitudes. European Journal of Social Psychology, 29, 329-348. https://doi.org/10.1002/(SICI)1099-0992(199903/05)29:2/3<329::AID-EJSP930>3.0. CO;2-6 
Submit or recommend next manuscript to OALib Journal and we will provide best service for you:

- Publication frequency: Monthly

- 9 subject areas of science, technology and medicine

- Fair and rigorous peer-review system

- Fast publication process

- Article promotion in various social networking sites (LinkedIn, Facebook, Twitter, etc.)

- Maximum dissemination of your research work

Submit Your Paper Online: Click Here to Submit

Or Contact service@oalib.com 